\title{
Two Cases of Nuclear Protein in Testis Midline Carcinomas of Sinonasal Tract
}

\author{
Minhyung Lee, Yong Seok Kang, Tae-Bin Won, and Hyun Jik Kim \\ Department of Otorhinolaryngology, Seoul National University College of Medicine, Seoul, Korea
}

\section{비부비동 영역의 NUT Midline Carcinoma 2예}

이민형 · 강용석 · 원태빈 · 김현직

서울대학교 의과대학 이비인후과학교실

\author{
Received September 29, 2016 \\ Revised October 22, 2016 \\ Accepted October 24, 2016 \\ Address for correspondence \\ Hyun Jik Kim, MD, PhD \\ Department of Otorhinolaryngology, \\ Seoul National University \\ College of Medicine, \\ 101 Daehak-ro, Jongno-gu, \\ Seoul 03080, Korea \\ Tel $+82-2-2072-2203$ \\ Fax $+82-2-735-2387$ \\ E-mail hyunjerry@snu.ac.kr
}

Nuclear protein in testis (NUT) midline carcinoma (NMC) is a rare and aggressive tumor that is genetically characterized by chromosomal rearrangement of the NUT gene. NMC predominantly involves the midline structures of the body and the sinonasal tract is considered a preferential site. While the optimal management of NMC is unclear, more than $80 \%$ of patients will die within one year of their diagnosis despite intensive treatment. We report two cases of NMC of the sinonasal tract. Histopathologic results of the punch biopsy showed undifferentiated and poorly differentiated carcinoma. NUT immunohistochemical staining results were positive. Multimodal treatments including surgery, radiotherapy, and chemotherapy were performed. We also present a literature review to compare with the present cases. In our cases, we emphasize the importance of the early diagnosis and intensive treatment of NMC.

Korean J Otorhinolaryngol-Head Neck Surg 2017;60(12):673-7

\section{서 론}

Nuclear protein in testis(NUT) midline carcinoma(NMC) 는 $15 q 14$ 염색체에 있는 NUT 유전자의 염색체 재배열을 특 징으로 하는, 매우 드물고 높은 사망률을 보이는 편평세포암 종의 한 아형이다. 복잡한 염색체 이상 배열을 보이는 전형적 인 고형암과 달리 NMC는 t(15;19) translocation 단일의 간단 한 핵형을 보이는 새로운 형태의 암종이다. ${ }^{1)} \mathrm{NUT}$ 유전자는 정상인에서 고환 조직에서만 발현되는 것으로 확인되었고, 그 기능은 아직 밝혀지지 않았다. 약 2/3에서 19p13.1 염색체 에 있는 BRD4 유전자가 NUT 유전자와 translocation하여 BRD4-NUT fusion oncogene을 형성하고, 나머지 1/3에서는

This is an Open Access article distributed under the terms of the Creative Commons Attribution Non-Commercial License (http://creativecommons.org/licenses/by-nc/4.0) which permits unrestricted non-commercial use, distribution, and reproduction in any medium, provided the original work is properly cited.
$\mathrm{BRD} 3$ 등 다른 유전자도 알려져 있다. ${ }^{2)} \mathrm{BRD} 4$ 는 $\mathrm{G} 2$ 에서 $\mathrm{M}$ 으로의 세포 주기를 조절함으로써 세포 증식에 중요한 역할 을 하는 것으로 밝혀졌다. $\mathrm{NMC}$ 에서 이러한 BRD4의 과발현 은 G1에서 S로의 진행을 억제하게 된다. BRD4-NUT fusion oncogene은 상피세포의 전구체에서 악성 변화를 일으키고, 동시에 편평세포 분화를 막아 저분화 또는 미분화 악성 종양 의 성장을 유도한다고 알려져 있다. ${ }^{2)}$

1991년에 22세의 여성에서 처음으로 이 새로운 형태의 미분 화암종이 흥선에서 발견되었다. t(15;19)(q14;p13.1) translocation이 확인되었고, 이는 BRD4-NUT 단백을 만드는 oncogene으로 밝혀졌다. 이러한 전위가 있는 종양들이 주로 비부 비동을 포함하여 몸 중앙선 주변 기관에서 생겨 NUT midline carcinoma라고 명명되었다. ${ }^{3)}$ 가장 흔히 상부기도소화기관 (50\%)과 종격동(41\%)에서 발생하며, 그 외에 이하선, 췌장, 부 신, 피하, 안구, 폐, 방광 그리고 장골 등에서도 보고되었다. ${ }^{1)}$ 
$\mathrm{NMC}$ 는 병리 소견만으로는 진단이 어려워 확진이 늦어지 거나 안 되는 경우가 많아 아직 발병률이 불명확하다. 두경부 영역에서 발생하는 미분화암종의 $18 \%$ 정도가 $\mathrm{NMC}$ 인 것으로 최근 논문들에서 보고되었다. ${ }^{45)}$ 처음 보고된 증례에서는 $\mathrm{NMC}$ 가 소아나 젊은 성인에 국한되는 것처럼 보였으나, 최근 에는 나이든 성인에서도 보고되고 있다. ${ }^{6)}$

$\mathrm{NMC}$ 는 reverse transcriptase-polymerase chain reaction(RT-PCR), fluorescence in situ hybridization(FISH), cytogenetic analysis로 NUT 유전자의 재배열을 확인함으 로써 진단이 가능하다. ${ }^{1)}$ 하지만 이러한 검사들은 일반적인 악 성 종양에서의 기본 검사에 해당하지 않고, 비용적 문제가 있 었으나 최근 NUT 항원에 대한 새로운 단클론성항체가 개발 되면서 NUT 면역조직화학염색을 통한 진단이 $87 \%$ 의 민감 도와 $100 \%$ 의 특이도를 보여줌으로써 좋은 대체제로 사용되 고 있다. ${ }^{7)}$

아직까지는 $\mathrm{NMC}$ 의 치료가 정립되어 있지 않다. $\mathrm{NMC}$ 는 매우 빠르게 주변으로 침범하고 이른 시기에 혈행성 전파를 하여 원격 전이가 흔하다. 때문에 다약제항암치료, 방사선 치 료, 수술적 치료 등 다양한 조합의 치료를 했지만 치료 결과 는 만족스럽지 않았고, 환자들의 평균 생존 기간은 6.7개월이 었다. ${ }^{6}$ 기존의 치료로써는 아직 근치적 치료가 어려워 새로운
치료에 대한 연구가 진행 중이다. BRD4-NUT oncoprotein 이 histone acetylation을 막아 세포 분화를 방해하는 사실에 근거하여 histone deactylase inhibitor와 bromodomain inhibitor의 임상적 사용이 연구 중이다. ${ }^{2)}$

현재 국내에서는 Park 등 ${ }^{8}$ 이 보고한 이하선에서 발생한 $\mathrm{NMC}$ 보고가 유일하다. $\mathrm{NMC}$ 의 주 발병 기관으로 비부비동 영역이 흔히 보고되고 있어 이비인후과의 역할이 중요하다고 할 수 있다. 이에 본 저자들은 9개월 동안 한 기관에서 발생 한 비부비동 영역의 $\mathrm{NMC}$ 두 증례를 보고하고자 한다.

\section{증 례}

서울대학교병원에서는 NUT 면역조직화학검사가 2015년 10월부터 시작되었다. 2015년 10월 1일부터 2016년 6월 30일 까지 총 9개월 동안 본원에서 NUT 면역조직화학검사상 NMC 로 진단을 받은 환자는 총 4 명이었다. 4 명의 환자 중 2 명은 폐 암으로 본 논문에서는 제외하였고, 비부비동 기원인 나머지 2 명의 의무 기록을 검토하였다.

\section{증 례 1}

8세 남자가 우측 코막힘을 주소로 이비인후과 외래로 내원
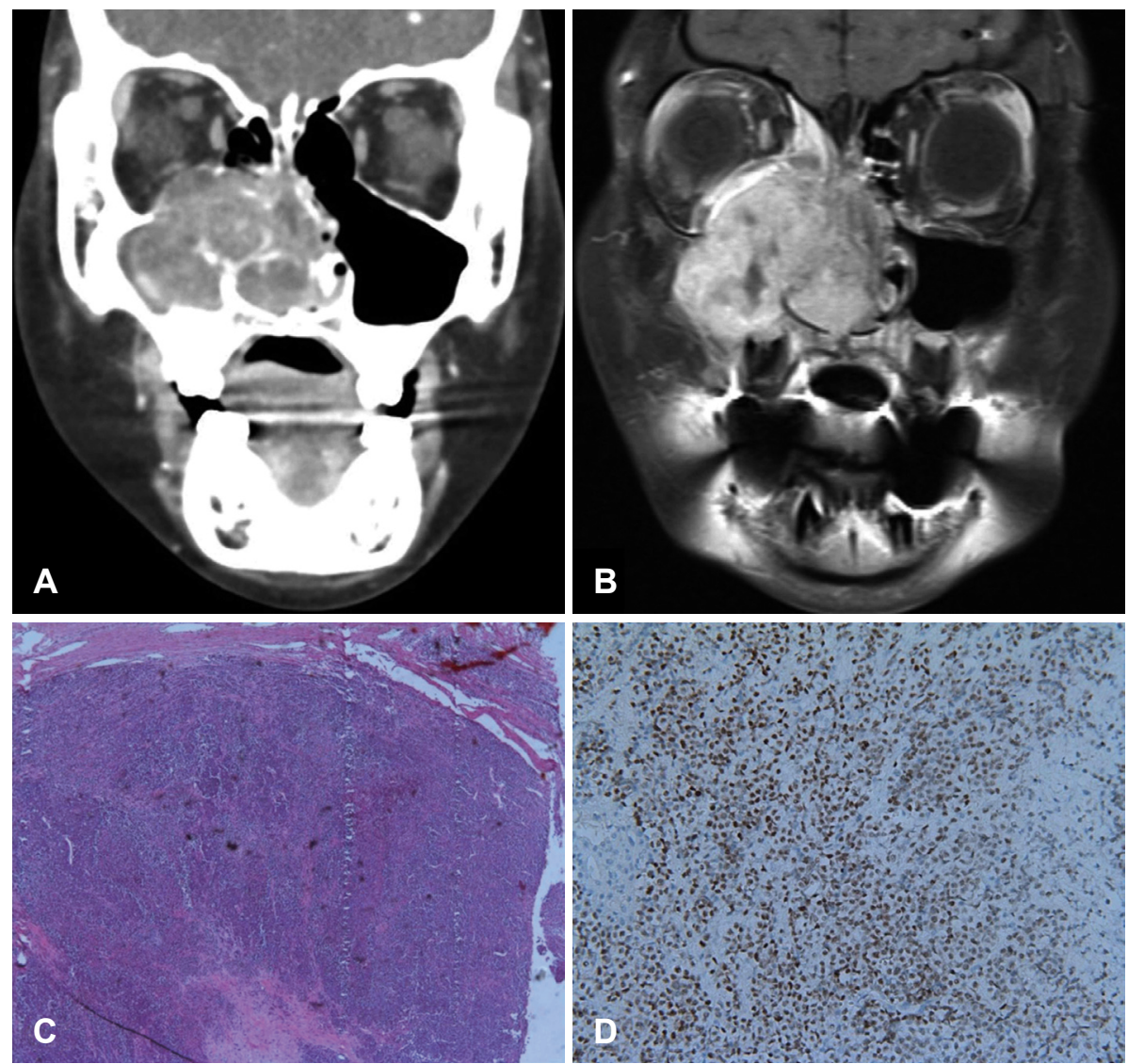

Fig. 1. CT image of case 1 patient before treatment. Heterogenous enhancing mass involving right maxillary sinus, nasal cavity, orbit and infratemporal fossa without intracranial involvement (A). MRI image of case 1 patient before treatment. T1 heterogenous high signal intense mass involving the right maxillary sinus, nasal cavity, orbit and infratemporal fossa without intracranial involvement with mass effect on inferior rectus muscle (B). Histopathologic finding of case 1 patient $(C, \times 40)$. NUT immunohistochemical staining of case 1 patient $(D, \times 200)$. NUT: nuclear protein in testis. 
하였다. 검진상 우측 비강을 채우는 과혈관성 종괴 소견을 확 인할 수 있었다. 이에 CT와 MRI를 시행하였고 $4.5 \mathrm{~cm}$ 크기의 우측 상악동을 중심으로 조영 증강을 보이는 종괴를 관찰할 수 있었다. 이는 우측 비강, 측두골하 공간을 침범하고 우측 안구를 누르는 양상을 보였다. 또한 우측 상악동의 상, 후, 내 측벽 및 비중격을 파괴하는 소견이 있었다(Fig. $1 \mathrm{~A}$ and B). 내시경하 조직검사를 시행하였고 미분화암종으로 진단되어 (Fig. 1C) positron emission tomography(PET) 검사를 시행 하였고 원격 전이를 시사하는 소견은 관찰되지 않았다. 이후 cisplatin, bleomycin, 5-fluorouracil 항암화학치료를 시작 하였다. 중간에 5-fluorouracil 관련 뇌병증 발생으로 epirubicin으로 변경하였다. 항암화학치료에 반응이 크지 않아 안 구를 보존하는 상악절제술을 시행하였고 해당 조직에서 면역 조직화학검사를 확인해 본 결과 NUT(Fig. 1D), cytokeratin, epithelial membrane antigen vimentin, FLI-1, P40에 양성 반 응을 보여 NMC로 확진되었다. 수술 후 docetaxel, ifosfamide, cisplatin 항암치료와 우측 상악에 $54 \mathrm{~Gy}$ 를 30회 분할하여 방 사선 치료를 진행하고 있다. 처음 미분화암종으로 진단받은 이래로 마지막 외래 방문까지인 9개월간 생존 중이다(Table 1).

\section{증 례 2}

65세 남자가 두통, 우측 안구 부종, 우측 시력 저하를 주소 로 본원 응급실로 내원하였다. 검진상 양측 중비갑개 사이에 종괴 소견을 확인할 수 있었다. 이에 MRI와 CT를 시행하였 고 $4.5 \mathrm{~cm}$ 크기의 우측 사골동을 중심으로 조영 증강을 보이 는 종괴를 관찰할 수 있었다. 이는 양측 사골동, 양측 비강, 양측 접형동, 전두개저를 침범하고 양측 안구를 누르는 양상 을 보였다(Fig. 2A and B). PET 검사상 원격 전이를 시사하 는 소견은 관찰되지 않았다. 내시경하 펀치생검을 시행하였 고 저분화암종으로 진단되었다(Fig. $2 \mathrm{C}$ ). 이에 추가로 면역조 직화학검사를 시행하였고 NUT(Fig. 2D), cytokeratin, P40 에 양성 반응을 보여 $\mathrm{NMC}$ 로 확진되었다. 환자는 내시경하

Table 1. Demographics, clinical findings of the patients

\begin{tabular}{|c|c|c|c|c|c|c|c|}
\hline 증례 & 성별/연령 & 흡연력 & 원발 부위 & 진단 & 전이 & 치료 & 생존 기간 \\
\hline 1 & 남/8 & 무 & 우측 상악동 & Undiff ca & 무 & CRS & 9개월, 현재 생존 \\
\hline 2 & 남/65 & 무 & 우측 사골동 & PD ca & 무 & CRS & 5개월, 현재 생존 \\
\hline
\end{tabular}

Undiff ca: undifferentiated carcinoma, PD ca: poorly differentiated carcinoma, CRS: chemotherapy, radiotherapy and surgery

Fig. 2. CT image of case 2 patient before treatment. Hyperdense mass in the nasal cavity, ethmoid sinus, sphenoid sinus, cribriform plate and anterior cranial fossa with right medial orbital wall destruction (A). MRI image of case 2 patient before treatment. T1 iso signal intense lesion in the superior nasal cavity, extending to the anterior skull base, bilateral medial orbits, sphenoid and ethmoid sinuses with lateral displacements of the medial rectus and superior oblique muscles (B). Histopathologic finding of case 2 patient (C, $\times 40)$. NUT immunohistochemical staining of case 2 patient $(D, \times 200)$. NUT: nuclear protein in testis.
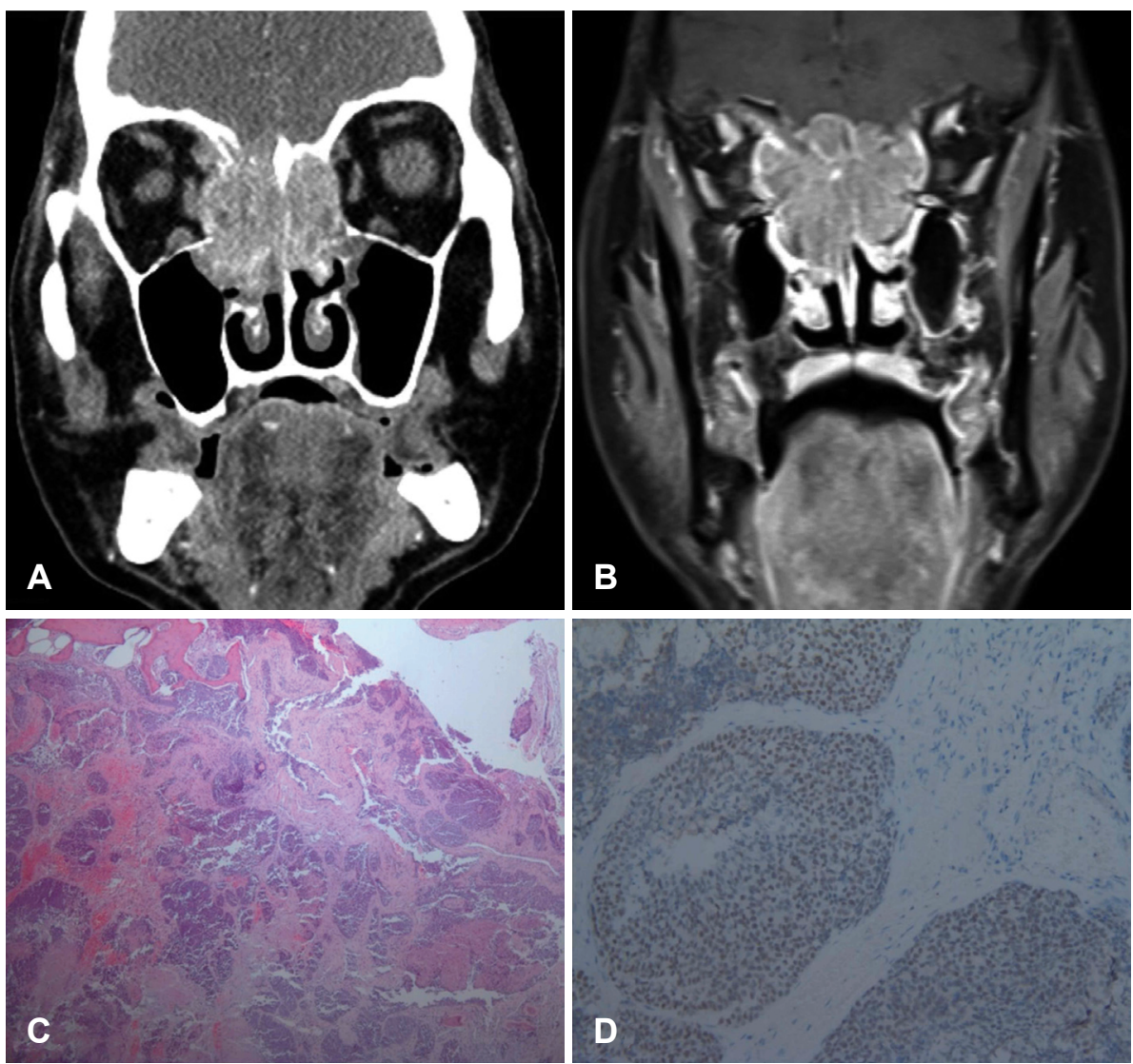
두개안면절제술 및 시신경감압술을 시행받았고 수술 후 67.5 $\mathrm{Gy}$ 를 30회 분할한 방사선 치료와 함께 cisplatin을 6주간 사 용하는 동시항암화학방사선 치료를 받았다. 이후 경과 관찰 중으로 펀치생검으로 확진을 받은 이래로 마지막 외래 방문 까지인 5 개월간 생존 중이다.

\section{고 찰}

본 증례들의 연령은 8세와 65 세였고 모두 남자이며 비흡연 자였다. 처음에는 $\mathrm{NMC}$ 가 소아 또는 젊은 성인에서 발생한다 고 보고하였으나 이는 세포유전학적 검사가 성인보다는 주로 소아의 악성 종양에서 자주 시행되기 때문에 발생하는 표본선 정 편파로 생각되고 있다. ${ }^{5)}$ 78세 환자 등 나이든 성인군에서 도 $\mathrm{NMC}$ 가 진단되어 모든 연령군에서 고려되어야 함을 보고 하였다. ${ }^{5)}$ Bishop과 Westra ${ }^{4}$ 는 151 명의 비부비동암 환자 중 $2 \%$ 가 $\mathrm{NMC}$ 임을 보고하였고 그들의 평균 연령은 36 세였고 모 두 남자이며 2명은 비흡연자였고 1명은 과거 흡연력이 있던 환 자였다. 일반적으로 흡연력이 있는 환자에서 비부비동암이 흔 하나 비부비동에서의 $\mathrm{NMC}$ 는 비흡연자에서 더 흔했다. ${ }^{7)}$ 그러 나 환자 수가 많지 않아 발생하는 오류일 가능성도 배제할 수 없다.

$\mathrm{NMC}$ 의 진단은 본 저자들의 병원에서 NUT 면역조직화 학검사를 통해 2015년 10월부터 시작하였다. 예전에는 RT$\mathrm{PCR}, \mathrm{FISH}$ 또는 cytogenetic analysis 등 유전자 검사를 통 해서만 진단이 가능했기 때문에 비용적 문제가 있었지만 NUT 면역조직화학검사가 가능해지면서 특이도 $100 \%$, 민감도 $87 \%$ 의 진단이 가능해졌다. 다만 NUT 면역조직화학검사상 양성 소견은 $\mathrm{NMC}$ 에만 국한된 것은 아니고 생식세포종에서도 양 성일 수 있다. 상부기도소화기관과 종격동에 발생한 미분화 암에서 $\mathrm{NMC}$ 뿐만 아니라 생식세포종의 전이 가능성도 고려 해야 한다. ${ }^{7}$

병리조직검사상 1 번 증례는 처음에 비인두 미분화암종으 로 진단되었고 NUT 면역조직화학검사를 시행하지 않았다. 이에 항암화학치료를 먼저 시작하였고 종괴의 크기가 줄어 드는 양상을 보였으나 효과의 한계가 있어 수술적 치료를 계 획하게 되었다. $\mathrm{NMC}$ 가능성을 확인하기 위해 수술 후 조직 에서 NUT 면역조직화학검사를 함께 시행하였고 수술 후에
$\mathrm{NMC}$ 로 확진되었다. 2 번 증례는 처음 펀치생검에서 비부비동 저분화암종으로 진단되었고 NUT 면역조직화학검사를 함께 시행하였다. 그래서 1 번 증례에 비해 좀 더 빨리 $\mathrm{NMC}$ 가 확진 되었다.

본 증례에서 NUT 외의 면역조직화학검사 결과는 통일된 검 사를 시행하지 않았지만 1번 증례에서 chromogranin, S-100, synaptophysin에 음성, 2번 증례에서 desmin, CD99, EpsteinBarr virus(EBV)에 음성 소견을 보였다(Table 2). 특징적으로 $\mathrm{NMC}$ 는 병리조직검사상 미분화암종을 제외하고는 $\mathrm{CD} 45$, S-100, HMB-45, CD99, desmin, myoglobin, smooth muscle actin, muscle actin, neuron-specific enolase, CD57, chromogranin, synaptophysin, alpha-fetoprotein, placental alkaline phophatase 면역조직화학검사상 음성을 확인함으로 써 다른 악성 종양과 감별 진단을 할 수 있다. 미분화암종과 의 감별 진단을 위한 면역조직화학검사에서 비인두암의 미 분화형의 경우 $\mathrm{EBV}$ 검사상 양성이지만 $\mathrm{NMC}$ 에서는 보고된 모든 경우에서 음성이었다. 비부비동 미분화암종의 경우 대부 분 $\mathrm{p} 63$ 의 반응이 없으나 $\mathrm{NMC}$ 에서는 대부분 $\mathrm{p} 63$ 의 면역반응 을 확인할 수 있었고 또한 $\mathrm{CD} 34$ 에 반응을 보였다.' $\mathrm{NMC}$ 진 단에 대해 Bauer 등흔 흥강 및 두경부에 발생하는 샘분화 가 없는 모든 저분화암종에 대해 NUT 면역조직화학검사를 할 것을 추천했다. 상피분화 여부는 검사의 결정에 영향을 주지 않지만, EBV 또는 human papilloma virus 감염 등 특 정한 원인이 먼저 확인된 경우는 검사를 필요로 하지 않는다 고 하였다.

$\mathrm{NMC}$ 의 치료는 아직 정립되지 않았다. 좀 더 빠른 시기에 방사선 치료를 시작할수록, 육안적으로 종양전절제가 가능 했을 때 생존 기간이 통계학적으로 유의미하게 증가하였으나, 항암치료는 효과를 입증하지 못했다고 보고했다. ${ }^{6}$ Chau 등미 은 48명의 두경부 영역에 발생한 $\mathrm{NMC}$ 환자들을 관찰하였 고 초기 치료로 광범위한 절제와 함께 절제 경계면에서 악성 세포가 확인되지 않을 때 통계학적으로 유의미하게 평균 생 존 기간 및 무진행 생존 기간을 향상시킨다고 보고했다. 반면 초기 치료로 방사선 치료 및 항암화학치료는 생존 기간에 유 의미한 영향을 주지 못했으나 보조 치료로써 중요한 역할을 한다고 하였다.

$\mathrm{NMC}$ 는 임상종양학의 분자학적 특성이 중요한 패러다임

Table 2. Immunohistochemical profile of NMCs

\begin{tabular}{ccccccc}
\hline \multirow{2}{*}{ 증례 } & \multicolumn{7}{c}{ Immunohistochemical staining } \\
\cline { 2 - 7 } & Chromogranin & S-100 & Synaptophysin & Desmin & CD99 & EBV \\
\hline 1 & $(-)$ & $(-)$ & $(-)$ & 시행 안함 & 시행 안함 & 시행 안함 \\
2 & 시행 안함 & $(-)$ & 시행 안함 & $(-)$ & $(-)$ & $(-)$ \\
\hline
\end{tabular}

NMCs: midline carcinomas, EBV: Epstein-Barr virus 
변화의 좋은 예이다. 해부학적 구조가 아니라 공통된 유전병 리생리학적 특성으로 통합된 질환이기 때문이다. 최근 생물 학적 연구의 진보와 함께 NMC에서 bromodomain-containing NUT fusion protein이 histone acetylation을 방해하여 세포의 분화를 막는 것으로 확인되었다. ${ }^{11)}$ 이 결과에서 histone deacetylase inhibitor 치료가 새로운 치료 방법으로 기대되고 있지만 아직 치료 효과는 입증하지 못했다. ${ }^{12,13)}$

본 증례들은 정보의 제한점이 있었다. 첫 번째로 아직 치료 중 또는 치료 종결 후 경과 관찰 중으로 생존 기간, 치료의 효과 및 완치 여부를 평가할 수 없었다. 1 번 증례의 경우 진단 후 9 개월, 2 번 증례의 경우 진단 후 5 개월째 경과 관찰 중이 다. 대부분의 환자는 증상 발생 이후 1 년 이내로 사망하였고, 평균 생존 기간은 9.5개월이었다. ${ }^{10)}$ 그중 비부비동 영역의 $\mathrm{NMC}$ 에서는 평균 생존 기간이 12 개월이었다. Bishop과 Westra ${ }^{4)}$ 의 논문에서는 3 명의 환자 모두 처음 진단 당시에 원격 전이 가 없었으나 사망 당시에는 3명 모두 원격 전이가 확인되었다. 치료 종결 후에도 경과 관찰을 하면서 재발 및 원격 전이에 대한 꾸준한 평가가 필요하겠다. 두 번째로 세포유전학적 검 사를 시행하지 않았다. NUT 유전자와 재배열을 한 유전자 가 어떤 것인지 확인할 수 없었다. 앞서 언급한 대로 BRD4$\mathrm{NUT} \mathrm{NMC가} \mathrm{2/3} \mathrm{정도를} \mathrm{차지하고,} \mathrm{BRD4} \mathrm{외의} \mathrm{다른} \mathrm{유전자}$ 와 재배열을 한 NUT variant $\mathrm{NMC}$ 가 $1 / 3$ 정도를 차지한다. ${ }^{2)}$ French 등 ${ }^{14)}$ 은 초기에는 NUT-variant NMC가 BRD4-NUT $\mathrm{NMC}$ 보다 더 좋은 예후를 보인다고 보고하였으나, 최근 연 구 결과에서는 차이가 없다고 보고하였다. ${ }^{15)}$ 향후 세포유전 학적 검사를 시행하여 유전자 차이에 따른 $\mathrm{NMC}$ 의 진행 양 상의 차이를 분석할 필요가 있겠다.

본 증례들은 비부비동 영역에서 $\mathrm{NMC}$ 의 진단과 치료 과정 을 잘 보여주는 좋은 예들이다. 추후 장기적인 추적 관찰을 통 해 치료 결과를 분석할 필요가 있겠다. $\mathrm{NMC}$ 는 드물고 높은 사망률을 보이지만 병리조직학적 검사만으로는 진단이 어려 운 질환이다. 이에 본 저자들은 비부비동 영역에서 발생한 저분화 또는 미분화암종에 대해 NUT 면역조직화학검사를
시행하여 빠른 진단과 치료가 시행되어야 함을 강조한다.

\section{REFERENCES}

1) French CA. Pathogenesis of NUT midline carcinoma. Annu Rev Pathol 2012;7:247-65.

2) French CA, Ramirez CL, Kolmakova J, Hickman TT, Cameron MJ, Thyne ME, et al. BRD-NUT oncoproteins: a family of closely related nuclear proteins that block epithelial differentiation and maintain the growth of carcinoma cells. Oncogene 2008;27(15): 2237-42.

3) Bellizzi AM, Bruzzi C, French CA, Stelow EB. The cytologic features of NUT midline carcinoma. Cancer 2009;117(6):508-15.

4) Bishop JA, Westra WH. NUT midline carcinomas of the sinonasal tract. Am J Surg Pathol 2012;36(8):1216-21.

5) Stelow EB, Bellizzi AM, Taneja K, Mills SE, Legallo RD, Kutok $\mathrm{JL}$, et al. NUT rearrangement in undifferentiated carcinomas of the upper aerodigestive tract. Am J Surg Pathol 2008;32(6):828-34.

6) Bauer DE, Mitchell CM, Strait KM, Lathan CS, Stelow EB, Lüer $\mathrm{SC}$, et al. Clinicopathologic features and long-term outcomes of NUT midline carcinoma. Clin Cancer Res 2012;18(20):5773-9.

7) Haack H, Johnson LA, Fry CJ, Crosby K, Polakiewicz RD, Stelow EB, et al. Diagnosis of NUT midline carcinoma using a NUT-specific monoclonal antibody. Am J Surg Pathol 2009;33(7):984-91.

8) Park HS, Bae YS, Yoon SO, Lim BJ, Hong HJ, Ro JY, et al. Usefulness of nuclear protein in testis (NUT) immunohistochemistry in the cytodiagnosis of NUT midline carcinoma: a brief case report. Korean J Pathol 2014;48(4):335-8.

9) Davis BN, Karabakhtsian RG, Pettigrew AL, Arnold SM, French CA, Brill YM. Nuclear protein in testis midline carcinomas: a lethal and underrecognized entity. Arch Pathol Lab Med 2011;135(11): 1494-8.

10) Chau NG, Hurwitz S, Mitchell CM, Aserlind A, Grunfeld N, Kaplan $\mathrm{L}$, et al. Intensive treatment and survival outcomes in NUT midline carcinoma of the head and neck. Cancer 2016;122(23):3632-40.

11) Schwartz BE, Hofer MD, Lemieux ME, Bauer DE, Cameron MJ, West NH, et al. Differentiation of NUT midline carcinoma by epigenomic reprogramming. Cancer Res 2011;71(7):2686-96.

12) Maur M, Toss A, Dominici M, Frassoldati A, Corradini P, Maiorana A, et al. Impressive response to dose-dense chemotherapy in a patient with NUT midline carcinoma. Am J Case Rep 2015;16:424-9.

13) Maher OM, Christensen AM, Yedururi S, Bell D, Tarek N. Histone deacetylase inhibitor for NUT midline carcinoma. Pediatr Blood Cancer 2015;62(4):715-7.

14) French CA, Kutok JL, Faquin WC, Toretsky JA, Antonescu CR, Griffin CA, et al. Midline carcinoma of children and young adults with NUT rearrangement. J Clin Oncol 2004;22(20):4135-9.

15) French CA. Demystified molecular pathology of NUT midline carcinomas. J Clin Pathol 2010;63(6):492-6. 